\title{
Regional carbon uptake of croplands in Poland between 1960 and 2009
}

\author{
Jędrzej Nyćkowiak, Jacek Leśny, Janusz Olejnik \\ Poznań University of Life Sciences, Faculty of Environmental Engineering and Spatial Management, 60-649 Poznań, \\ Piątkowska94E,Poland,e-mail: jedrzej.nyckowiak@gmail.com,jlesny@au.poznan.pl,olejnikj@up.poznan.pl
}

\section{Lutz Merbold}

ETH Zürich, Department of Environmental Systems Science, Institute of Agricultural Sciences Switzerland, LFW C 57.1, Universitätstrasse 2, 8092 Schweiz, Switzerland, e-mail: lutz.merbold@ipw.agrl.ethz.ch

Shuli Niu

Institute of Geographic Sciences and Natural Resources Research, Chinese Academy of Sciences, 11A, Datun Road, Chaoyang District, Beijing 100101, People's Republic of China, e-mail: sniu@igsnrr.ac.cn

\begin{abstract}
Croplands have been identified as binding large amounts of carbon. About one third of the total area in Poland is covered by croplands. In this paper, we analyze data describing the yields and structure of crops available for 13 selected subareas of Poland between 1960 and 2009 to evaluate the greenhouse gas mitigation potential due to carbon (C) uptake of this land cover type. Seven selected subareas located in Western Poland (area A), and six subareas in the southeast of Poland (area B) were chosen for detailed analysis. Cereals were identified as the most dominant crop planted in both areas during 1960-2009. Still, differences in yield could be found, with larger production in area A than in area B. By the year 2009, arable land (cereals, beetroot, potato, rapeseed and maize) covered nearly 10 Mio ha of Poland. The average uptake of $\mathrm{C}$ by crops between 1960 and 2009 was 3,24 $\pm 0,17 \mathrm{Mg} \mathrm{C} \mathrm{ha}^{-1} \mathrm{a}^{-1}$ for area A, 2,84 $\pm 0,12 \mathrm{MgC} \mathrm{ha}^{-1} \mathrm{a}^{-1}$ for area B and 2,88 $\pm 0,11 \mathrm{MgC} \mathrm{ha}^{-1} \mathrm{a}^{-1}$ for the whole country. Given the fact that about $3 \%$ of the total assimilated carbon remains in the soil, we calculated that $0,98 \mathrm{Tg} \mathrm{C}$ were stored in Polish croplands in 2009. Due to this fact, croplands are short time storage of carbon and thus contribute to greenhouse gas mitigation.
\end{abstract}

Keywords: carbon sink, IPCC methodology, yields

Submitted 24 April 2017, revised 28 July 2017, accepted 17 November 2017

\section{Introduction}

Terrestrial ecosystems exchange carbon dioxide $\left(\mathrm{CO}_{2}\right)$ due to plant photosynthesis and respiration (Schlesinger, Andrews 2000). If photosynthesis exceeds respiration, ecosystems act as carbon sinks and, if vice versa, as a carbon source. Such sink/source knowledge is important due to ongoing climate change caused by a rise in atmospheric $\mathrm{CO}_{2}$ concentrations through the burning of fossil fuels, land-use and land-use changes (Anderson et al. 2016). Studies focusing on the long-term variations in $\mathrm{CO}_{2}$ exchange (source/ sink behaviour) are of great importance (e.g. Owensby et al. 1999; Bousquet et al. 2000; Acosta et al. 2017), and also play indirectly an important role in decreasing pollution and the emission of greenhouse gases (Andres et al. 2012; Seinfeld, Pandis 2016; Venhari et al. 2017).

Therefore, we aim in the current study to analyse the carbon sink strength of major crop types in Poland between 1960 and 2009 using the IPCC methodology (IPCC 2006b).
It has been stated that the most popular crops in Poland are cereals (GUS 1966-2014). Cereals transfer about $20-30 \%$ of the total assimilated carbon to the soil (Kuzyakov, Domański 2000). Belowground residues of plants are converted to soil organic matter (SOM) and therefore contribute to soil organic carbon (SOC). Enhanced conversion of residues to SOM results in larger soil organic carbon stocks (Ontl, Schulte 2012; Khedr et al. 2017). While carbon in aboveground biomass of crops can be measured easily, belowground biomass can hardly be measured in situ (Houghton et al. 2009; Magalhães 2015; Shafea et al. 2017), and must therefore be estimated. One possibility of estimating belowground biomass is based on the equations provided in the instructions of the Guidelines for national greenhouse gas inventories (IPCC 2006b). Using these, national data describing yields (provided by the Central Statistical Office of Poland (GUS)) are used to reliably calculate aboveground and belowground biomass.

Such analysis is becoming of great importance, since more than 10 million hectares (above $32 \%$ of the area 
of the country) are currently planted with cereals, potato, beetroot, rapeseed and maize (GUS 2014) and it remains unclear whether cropping systems in Poland can mitigate greenhouse gas emissions.

The specific objectives of this study are: to analyse the variation in $\mathrm{C}$ uptake by crops (cereals, potato, beetroot, rapeseed and maize) in Poland between 1960-2009, and to evaluate the greenhouse gas mitigation potential of Polish croplands.

\section{Material and methods}

\subsection{Study area}

In this study, we present thirteen subareas (former provinces) representing two cropping areas in Poland. Seven subareas are located in western Poland (area A) and six in south-east Poland (area B) (Fig. 1). Both areas varied in respect of farm sizes, the amount of fertilizers used annually, average crop yields, and crop structure (Nyćkowiak et al. 2014a).

Historical developments are the main reason for different farm structures in areas A and B. While area A, located in western Poland, belonged to Prussia between 1795 and 1918, area B, located in the south-east of Poland, belonged to Russia (Bański 2007). This situation resulted in better economic development in western Poland, where great German estates were located ( $>20 \mathrm{ha}$ ). These estates were transformed state-owned collective farms after the Second World War and existed for 50 years. Then, as a result of the political and economic transformation in 1989, farms previously owned by the state were privatized. Still, their location and size has not change. In contrast, farms located in south-east Poland (area B) rarely exceeded 20 hectares. Such land fragmentation was primarily the result of the habit of passing land down from parents to several children. A result of the large differences in farm structure between area A and B, is vastly differing in crop yields, crop structure, fertilizer application and nitrous oxide emissions. (see also Nyćkowiak et al. 2014a)
Mean annual temperatures were $8,4^{\circ} \mathrm{C}\left(\mathrm{SD}=0,9^{\circ} \mathrm{C}\right)$ and $7,9^{\circ} \mathrm{C}\left(\mathrm{SD}=0,9^{\circ} \mathrm{C}\right)$ and precipitation was $542 \mathrm{~mm}$ $(\mathrm{SD}=96 \mathrm{~mm})$ and $610 \mathrm{~mm}(\mathrm{SD}=117 \mathrm{~mm})$ for the years 1960-2009 for areas A and B, respectively. Climate diagrams Walter and Lieth (1967; Nyćkowiak et al. 2014b) created in this study indicate mean monthly temperatures and precipitation patterns for individual months in an average year (Fig. 2).

\subsection{Carbon uptake calculations}

Yearly data of agricultural land use during 1960-2009 were derived from publications of the Central Statistical Office of Poland (GUS). Long-term statistical data used in this study include crop yields $\left(\mathrm{Mg} \mathrm{ha}^{-1} \mathrm{a}^{-1}\right)$, the crop structure of cereals (barley, oat, wheat and rye), potato, beetroot, rapeseed and maize as well as the percentage of area under crop production in Poland (GUS 1966, 1967a, 1976b, 1967c, 1970, 1971, 1976, 1978, 1982, 1985, 1986, 1987, 1990, 1992a, 1992b, 1993, 1994a, 1994b, 1995, 1996, 1997, 1998, 1999a, 1999b, 2000, 2001a, 2001b, 2002, 2003, 2004, 2005a, 2005b, 2006a, 2006b, 2007a, 2007b, 2008a, 2008b, 2009a, 2009b, 2010).

Carbon uptake of crops was calculated by the increase in aboveground and belowground biomass over time. While changes in aboveground biomass of crops can be easily estimated by measuring the harvested biomass, it remains a major challenge to measure changes in belowground biomass in situ. Still, an estimation of changes in both aboveground and belowground biomass can be achieved with the equations and factors provided in the Guidelines for national greenhouse gas inventories (IPCC 2006b). Using these, carbon uptake is calculated as follows:

$$
\operatorname{Sink}_{C}=\sum_{T}\left\{\left(\operatorname{Crop}_{(T)}+A G_{(T)}+R_{B G(T)} \cdot \operatorname{Crop}_{(T)}\right) \cdot 0,45\right\}
$$

where: $\operatorname{Sink}_{C}$ represents the net C uptake by plants; $\operatorname{Crop}_{(T)}$ means the harvested annual dry matter for the specific crop

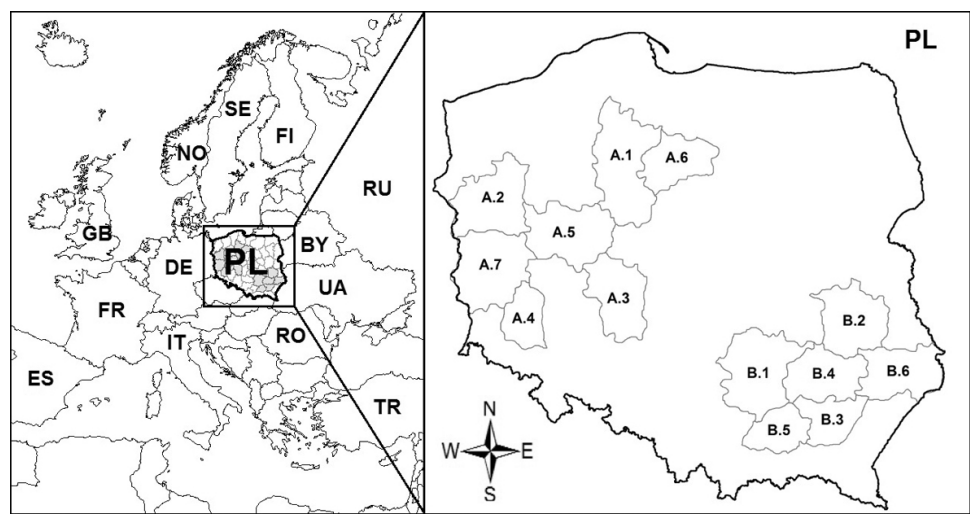

Fig. 1. Location and distribution of two major cropping areas in Poland 

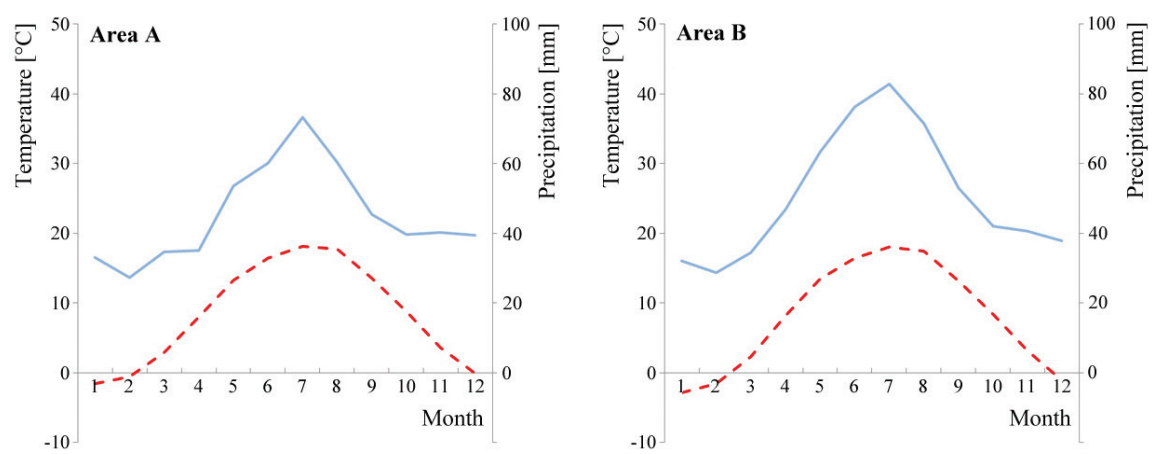

Fig. 2. Climate diagram with average monthly temperatures (dashed line) and sum of monthly precipitation (solid line) for (a) area A and (b) area B between 1960-2009

$T$ estimated as fresh matter multiplied by a conversion factor to derive the dry matter fraction; $A G_{(T)}$ stands for the dry matter of aboveground residues for the defined crop $T ; R_{B G(T)}$ is the ratio of belowground residues to harvested yield for crop $T$ (IPCC 2006b). The constant value of 0,45 has been suggested as the typical fraction of carbon in dry matter of plants (Barbour et al. 1987; Kirschbaum et al. 2001). Average $C$ uptake of both regions was calculated as the weighted average of all subareas per region.

Total $\mathrm{C}$ uptake of crops in Poland during the period 1960 and 2009 was based on the proportions obtained for the 49 former provinces in 1977 (Nyćkowiak et al. 2014a). With this information, we assume that the spatial variability in $\mathrm{C}$ uptake was similar for the whole period of analysis, i.e., 1960-2009. We assumed that the uptake in each individual province in a specific year is proportional to the mean from all of the analysed subareas for the same year. Hence, equation (2) provides an estimate of the $\mathrm{C}$ uptake by crops for the Polish territory:

$$
M_{Y}=\frac{A_{Y} \cdot M_{1977}}{A_{1977}}
$$

where: $M_{Y}$ is the quantity of $\mathrm{C}$ uptake from an area $(M)$ in this case the agricultural area of Poland - in a specific year $(Y) ; A_{Y}$ gives the average uptake of $\mathrm{C}$ for the specified subareas in year $(Y)$. A similar approach, which focused on nitrous oxide emissions from Polish agriculture, was applied by Nyckowiak et al. (2014a).

\subsection{Uncertainty analysis}

Uncertainties in the estimation of the net $\mathrm{C}$ uptake from agricultural crops exist for three major reasons: (1) the accuracy of statistical data (used raw data from GUS), (2) the estimation of aboveground and belowground dry matter residues with a set equation (Bouwman et al. 2002a-b; IPCC 2006a; Stehfest, Bouwman 2006) and (3) the accuracy of carbon content in dry matter (Houghton et al. 1985; Kirschbaum et al. 2001). The highest uncertainties are associated with the amount of dry matter residues (between 20-50\%) and carbon content in biomass (approximately 10\%) (IPCC 2006a-b; Kirschbaum et al. 2001).

\section{Results}

\subsection{Crop diversity and yields}

The dominant crop type in both areas during the period of 1960-2009 was cereal. The amount of cereals increased in the analysed period, from 68 and $75 \%$ in 1960 to 80 and $87 \%$ in 2009 (areas A and B, respectively). The planted area of potato was the second largest, followed by beetroot, rapeseed and maize.

During the period of 1960-2009, higher yields of cereals, potato and rapeseed were observed in area A, while yields of beetroot and maize were higher in area B (Table 1). A comparison of 1960 and 2009 showed that for all crops analysed in this study, yields were at least $45 \%$ higher in 2009 than in 1960 (Table 2). The largest increase observed for cereals was above $100 \%$ for area A.

\subsection{Temporal variation of carbon uptake by crops}

Temporal variation of carbon uptake by crops in A and B areas of Poland was diversified in years 1960-2009 (Fig. 3). Estimations showed larger quantities of $\mathrm{C}$ uptake for the whole period in area $\mathrm{A}$ than in area $\mathrm{B}$, average uptake was as high as $0,40 \mathrm{MgCha}^{-1} \mathrm{a}^{-1}$. An average uptake for area $\mathrm{A}$ in the period 1960-2009 was 3,24 $\mathrm{MgCha}^{-1} \mathrm{a}^{-1}$ (Fig. 3). In the period of 1960-1990 a strong increase in $\mathrm{C}$ uptake was observed in area $\mathrm{A}$, from 2,10 $\mathrm{MgCha}^{-1} \mathrm{a}^{-1}$ in 1960 to $4,14 \mathrm{MgCha}^{-1} \mathrm{a}^{-1}$ in 1990 (Fig. 3 and 6). A sudden drop in C uptake occurred in 1991-1992, with $\mathrm{C}$ uptake decreasing to $2,69 \mathrm{MgCha}^{-1} \mathrm{a}^{-1}$. The estimated total uptake of $\mathrm{C}$ by crops in area $\mathrm{B}$ was on average 2,84 MgCha-1 $\mathrm{a}^{-1}$ between 1960-2009 (Fig. 3). The average uptake from area B was $1,78 \mathrm{MgCha}^{-1} \mathrm{a}^{-1}$ in 1960. Similarly to area A, the uptake increased until 1990, reaching 
Table 1. Average crop yields of cereals, potato, beetroot, maize and rapeseed $\left[\mathrm{Mg} \mathrm{ha}^{-1} \mathrm{a}^{-1}\right]$ in areas $\mathrm{A}$ and $\mathrm{B}$ between 1960 and 2009 (for maize 1990-2009); in parentheses the standard deviations are shown

\begin{tabular}{|l|c|c|c|c|c|}
\hline \multirow{2}{*}{ Area } & \multicolumn{5}{|c|}{ Yields $\left[\mathrm{Mg} \mathrm{ha}^{-1} \mathrm{a}^{-1}\right]$} \\
\cline { 2 - 6 } & Cereals & Potato & Beetroot & Maize & Rapeseed \\
\hline A & $2,86( \pm 0,58)$ & $17,99( \pm 2,84)$ & $33,52( \pm 6,81)$ & $4,91( \pm 0,92)$ & $1,99( \pm 0,55)$ \\
\hline B & $2,48( \pm 0,42)$ & $17,00(1,74)$ & $35,39( \pm 5,60)$ & $5,08( \pm 0,64)$ & $1,78( \pm 0,42)$ \\
\hline
\end{tabular}

Table 2. Crop yield of cereals, potato, beetroot, maize and rapeseed $\left[\mathrm{Mg} \mathrm{ha}^{-1} \mathrm{a}^{-1}\right]$ in areas A and B in 1960 and 2009; in parentheses the standard deviations are shown

\begin{tabular}{|c|c|c|c|c|c|c|}
\hline \multirow{2}{*}{ Year } & \multirow{2}{*}{ Area } & \multicolumn{5}{|c|}{ Yields $\left[\mathrm{Mg} \mathrm{ha}^{-1} \mathrm{a}^{-1}\right]$} \\
\hline & & Cereals & Potato & Beetroot & Maize & Rapeseed \\
\hline \multirow{2}{*}{1960} & A & $1,78( \pm 0,14)$ & $13,76( \pm 1,02)$ & $25,86( \pm 1,77)$ & $0,00(-)$ & $1,41( \pm 0,29)$ \\
\hline & B & $1,49( \pm 0,05)$ & $12,40( \pm 1,67)$ & $27,70( \pm 2,69)$ & $0,00(-)$ & $1,33( \pm 0,28)$ \\
\hline \multirow{2}{*}{2009} & A & $3,83( \pm 0,20)$ & $21,15( \pm 1,52)$ & $51,76( \pm 4,94)$ & $5,99( \pm 0,50)$ & $3,31( \pm 0,22)$ \\
\hline & B & $2,98( \pm 0,13)$ & $18,04( \pm 1,07)$ & $52,33( \pm 5,39)$ & $5,74( \pm 0,18)$ & $2,28( \pm 0,40)$ \\
\hline \multicolumn{7}{|c|}{ Increase of yields [\%, 1960 as baseline $]$} \\
\hline \multirow{2}{*}{2009} & A & 115 & 54 & 100 & - & 135 \\
\hline & B & 100 & 45 & 89 & - & 71 \\
\hline
\end{tabular}

3,43 $\mathrm{MgCha}^{-1} \mathrm{a}^{-1}$. In area B, a sudden drop in C uptake was also observed in 1992 (2,90 $\left.\mathrm{MgCha}^{-1} \mathrm{a}^{-1}\right)$. During 1993 to 2009, C uptake by crops in both areas fluctuated between 2,61 to $4,50 \mathrm{MgCha}^{-1} \mathrm{a}^{-1}$.

Table 3 presents determination coefficients of $\mathrm{C}$ uptake for the areas $\mathrm{A}$ and $\mathrm{B}$ with doses of mineral $\mathrm{N}$ fertilization; mean yearly temperatures and precipitation sums; nitrous oxide emissions from arable land during the years 1960-2009.

\subsection{Crop contribution to total carbon uptake}

The total carbon uptake during the period from 1960 to 2009 was based on five dominant crop types (Table 4). The largest contributor to the total $\mathrm{C}$ uptake was cereal.
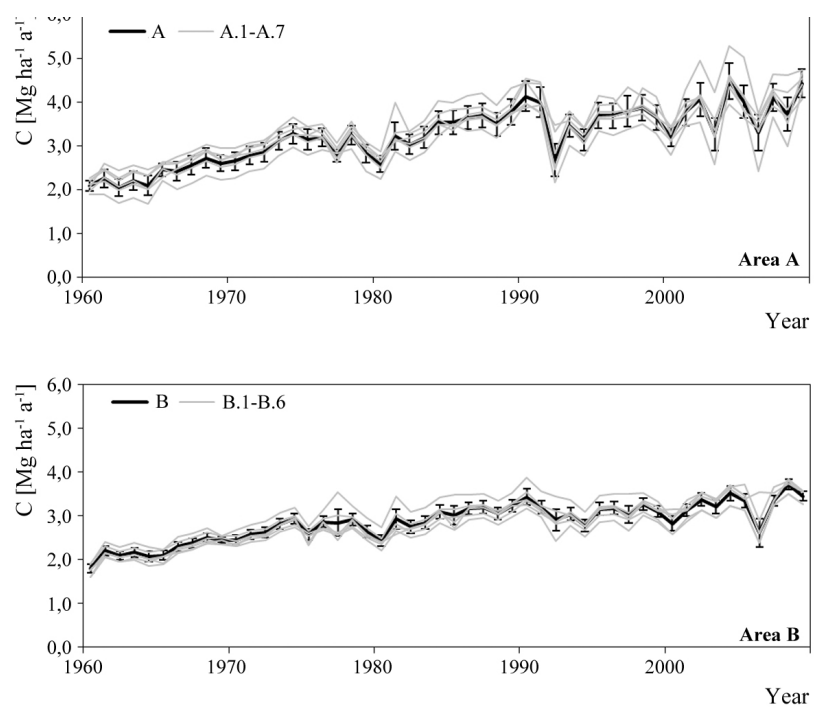

Fig. 3. Total annual $\mathrm{C}$ uptake by crops $\left[\mathrm{Mg} \mathrm{ha}^{-1} \mathrm{a}^{-1}\right]$ for area $\mathrm{A}$ and area B between 1960 and 2009; bars indicate $95 \%$ confidence interval (A: $n=7 ; \mathrm{B}: n=6$ )
The uptake by potato accounted for $50 \%$ of the remaining total uptake in the area $\mathrm{A}$ and more than $50 \%$ in area B.

A comparison of 1960 and 2009 showed that the biggest share in the total $\mathrm{C}$ uptake occurred from cereals (Fig. 4 and Table 5). The uptake by cereals in the last year of the analysed period accounts for more than $80 \%$ of the total $\mathrm{C}$ uptake in both areas. Nevertheless, the contribution of rapeseed and maize to the total $\mathrm{C}$ uptake showed an upward trend in both areas. This increase most likely occurred due to an upward trend in the cultivated area under grape seed and maize. However, we simultaneously observed decreases in components from potato and beetroot in both areas (Fig. 4 and Table 5).
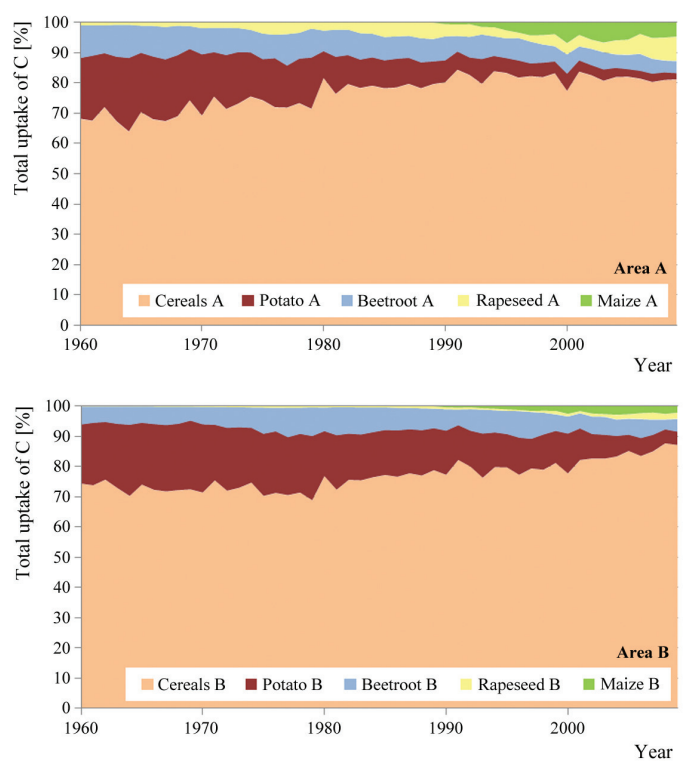

Fig. 4. Components of total $\mathrm{C}$ uptake [\% of total uptake] in areas A and B from crops such as cereals, potato, beetroot, maize and rapeseed between 1960 and 2009 
Table 3. Coefficients of determination between yearly values of $\mathrm{C}$ uptake and fertilizer application (mineral and organic), temperatures, precipitation and $\mathrm{N}_{2} \mathrm{O}-\mathrm{N}$ emission in the years 1960-2009

\begin{tabular}{|l|c|c|}
\hline \multirow{2}{*}{} & \multicolumn{2}{|c|}{$\begin{array}{c}\text { Determination } \\
\text { coefficients }\end{array}$} \\
\cline { 2 - 3 } & $\mathrm{A}$ & $\mathrm{B}$ \\
\hline $\begin{array}{r}\text { Fertilization: } \\
\text { Mineral }\left[\mathrm{kg} \mathrm{N} \mathrm{ha}^{-1} \mathrm{a}^{-1}\right]\end{array}$ & 0,53 & 0,49 \\
Organic $\left[\mathrm{kg} \mathrm{N} \mathrm{ha}^{-1} \mathrm{a}^{-1}\right]$ & 0,01 & 0,22 \\
\hline Temperature $\left[{ }^{\circ} \mathrm{C}\right]$ & 0,18 & 0,10 \\
\hline Precipitation $[\mathrm{mm}]$ & 0,01 & 0,02 \\
\hline $\mathrm{N}_{2} \mathrm{O}-\mathrm{N}$ emission $\left[\mathrm{kg} \mathrm{N} \mathrm{ha}{ }^{-1} \mathrm{a}^{-1}\right]$ & 0,75 & 0,50 \\
\hline Fertilization $(1960-1991)$ & & \\
Mineral $\left[\mathrm{kg} \mathrm{N} \mathrm{ha}^{-1} \mathrm{a}^{-1}\right]$ & 0,60 & 0,52 \\
\hline
\end{tabular}

Table 4. Contribution to total C uptake from different crop types in the period 1960-2009

\begin{tabular}{|l|c|c|c|c|c|}
\hline \multirow{2}{*}{ Area } & \multicolumn{5}{|c|}{ Crop type [\%] } \\
\cline { 2 - 6 } & Cereals & Potato & Beetroot & Maize & Rapeseed \\
\hline A & 75,5 & 9,7 & 7,1 & 4,4 & 3,3 \\
\hline B & 76,3 & 14,5 & 6,7 & 1,9 & 0,6 \\
\hline
\end{tabular}

Table 5. Contribution of the different crop types to total C uptake in 1960 and 2009

\begin{tabular}{|c|c|c|c|c|c|c|}
\hline \multirow{2}{*}{ Year } & \multirow{2}{*}{ Area } & \multicolumn{5}{|c|}{ Crop types } \\
\cline { 3 - 7 } & & Cereals & Potato & Beetroot & Maize & Rapeseed \\
\hline \multirow{6}{*}{1960} & A & 68,1 & 20,2 & 10,8 & 0,0 & 0,9 \\
\hline & B & 74,3 & 19,6 & 6,0 & 0,0 & 0,1 \\
\hline \multirow{2}{*}{2009} & A & 81,1 & 2,3 & 3,9 & 4,7 & 8,0 \\
\hline & B & 87,0 & 4,5 & 4,2 & 2,3 & 2,0 \\
\hline \multirow{7}{*}{1960} & A & 3,18 & 0,94 & 0,51 & 0,00 & 0,04 \\
\hline & B & 2,94 & 0,78 & 0,24 & 0,00 & 0,00 \\
\hline \multirow{2}{*}{2009} & A & 7,99 & 0,22 & 0,39 & 0,47 & 0,79 \\
\hline & B & 6,66 & 0,35 & 0,32 & 0,17 & 0,15 \\
\hline
\end{tabular}

\subsection{C uptake for the whole territory of Poland}

The upscaling of carbon uptake by croplands was based on a similar approach to the one used in Nyćkowiak et al. (2014a). The selected areas (A and B) served as the typical cropland area for the whole country. The estimated average value of the total $\mathrm{C}$ uptake by crops in Poland was 2,88 $\mathrm{MgCha}^{-1} \mathrm{a}^{-1}$ between 1960-2009. During the same period, continuous increases in $\mathrm{C}$ uptake were observed, from $1,83 \mathrm{MgCha}^{-1}$ in 1960 to $3,60 \mathrm{MgCha}^{-1}$ in 1990 (Fig. 3 and 5). A sudden decrease in $\mathrm{C}$ uptake was observed in 1992 (reduced to 2,62 $\mathrm{MgCha}^{-1}$ ). Since then, C uptake from croplands has fluctuated between $2,79 \mathrm{Mg} \mathrm{Cha}^{-1} \mathrm{a}^{-1}$ and 3,85 $\mathrm{Mg} \mathrm{Cha}^{-1} \mathrm{a}^{-1}$ until today.

\subsection{Spatial heterogeneity in $\mathrm{C}$ uptake by croplands}

When analysing the data, several hot spots of $\mathrm{C}$ uptake could be identified (Fig. 7, province H.1, A.4 and A.5 with 3,59; 3,57 and 3,50 $\mathrm{MgCha}^{-1} \mathrm{a}^{-1}$, respectively). Similarly, areas of reduced $\mathrm{C}$ uptake were found, e.g. H.2, H.3 and H.4 (1,94; 2,15 and 2,18 $\mathrm{MgCha}^{-1} \mathrm{a}^{-1}$, respectively) (Fig. 6). Still, C uptake was greater in western Poland than in the east. This difference became even more obvious after 1990 (Fig. 5 and Fig. 7). 


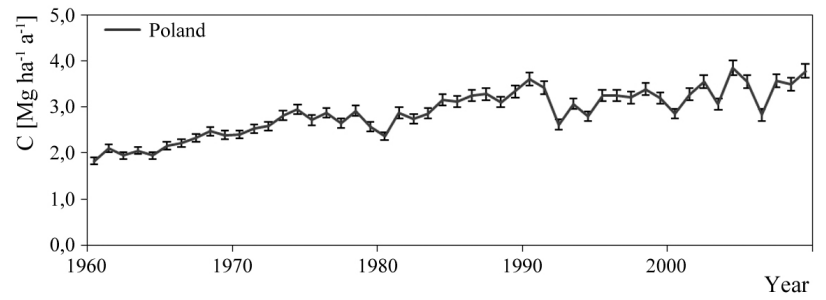

Fig. 5. Average annual C uptake of croplands $\left[\mathrm{Mg} \mathrm{ha}^{-1} \mathrm{a}^{-1}\right]$ between 1960 and 2009 in Poland; bars indicate 95\% confidence interval $(n=49)$

\subsection{Uncertainty analysis}

Uncertainty estimation of carbon uptake for the period of 1960-2009 (Table 6 and 7) in area A was 23\% on average (minimum and maximum amount of uptake was 2,90 and 3,97 $\mathrm{MgCha}^{-1} \mathrm{a}^{-1}$ ), whereas in area $\mathrm{B}$ it was $24 \%$ (min. 2,51 and max. C uptake 3,53 $\mathrm{Mg} \mathrm{C} \mathrm{ha}^{-1} \mathrm{a}^{-1}$ ). Uncertainties resulted from biases in calculations of the aboveground and belowground residues (IPCC 2006a) and carbon content of the dry matter $(0,45$ to 0,50 ; Kirschbaum et al. 2001).

\section{Discussion}

This study shows estimates of carbon uptake in croplands for two selected regions in Poland. The choice of the two regions was dictated by the different degree and level of management. For several centuries, area A had the intensive growing culture of European agriculture. This fact was further strengthened in 1772-1918, when Poland was divided by partitions and the country became occupied by Prussia, Russia and Austria-Hungary (Bański 2007). As a result of the partitions, the western region, which is contemporarily within Polish borders, had much better conditions for development than the eastern areas (Bański 2007). Farms from western Poland were included in big estates and converted into state-owned collective farms

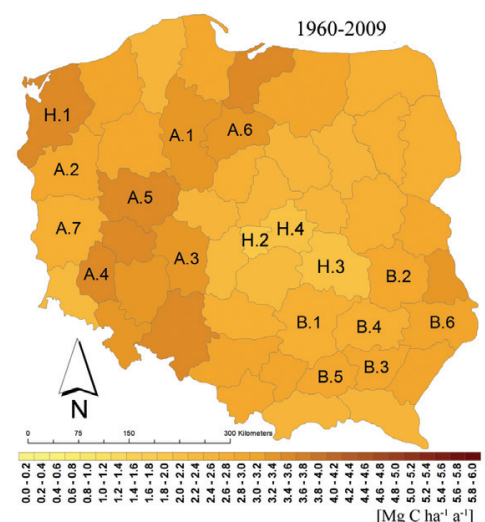

Fig. 6. Average $\mathrm{C}$ uptake $\left[\mathrm{MgCha}^{-1} \mathrm{a}^{-1}\right]$ from crops between 1960 and 2009; provinces A.1 - A.7 for area A and provinces B.1 - B.6 for area B, provinces H.1 - H.4 indicates hot spots

after the Second World War (Bański 2007). Their size and structure has often remained unchanged until today. Eastern parts of Poland were in a different condition, as state-owned collective farms did not play a significant role. The land was dominated by small family farms, supported less by the government when compared to state-owned collective farms in the west. This opposite development resulted in smaller amounts of mineral fertilizers being applied and subsequently brought lower yields (Nyćkowiak et al. 2014a). Larger C uptake in western Poland, as estimated for the time span 1960-2009, most likely occurred due to the more efficient management of farmland. Differences in farm management between the east and west are primarily visible in the crop cultures as well as the yields (Table 1). Although both areas were located within Polish territory after the First and Second World Wars, and development investment was in the same order of magnitude, the abovementioned historical differences have not been overcome to this day (Bański 2007) (Table 4).

Between 1960 and 1991, an upward trend in the uptake of $\mathrm{C}$ by crops was observed in both analysed areas.

Table 6. Uncertainties for A1 - A.7 and B.1 - B.6 subareas in the period of 1960-2009

\begin{tabular}{|c|c|c|c|c|c|c|c|c|c|c|c|c|}
\hline \multicolumn{10}{|c|}{ Uncertainties for regions A and B [\%] } \\
\hline A.1 & A.2 & A.3 & A.4 & A.5 & A.6 & A.7 & B.1 & B.2 & B.3 & B.4 & B.5 & B.6 \\
\hline 23 & 22 & 23 & 23 & 23 & 22 & 23 & 24 & 24 & 24 & 24 & 25 & 24 \\
\hline
\end{tabular}

Table 7. Minimum and maximum average uptake of C for A1 - A.7 and B.1 - B.6 subareas in the period of 1960-2009

\begin{tabular}{|c|c|c|c|c|c|c|}
\hline \multicolumn{7}{|c|}{ Range of uptake $\left(\mathrm{Mg} \mathrm{C} \mathrm{ha}^{-1} \mathrm{a}^{-1}\right)$} \\
\hline A.1 & A.2 & A.3 & A.4 & A.5 & A.6 & A.7 \\
$2,9-3,9$ & $2,6-3, \mathrm{q} 5$ & $2,9-3,9$ & $3,2-4,4$ & $3,1-4,3$ & $3,0-4,1$ & $2,5-3,4$ \\
\hline \multicolumn{7}{|c|}{ Region B } \\
\hline B.1 & B.2 & B.3 & B.4 & B.5 & B.6 & \\
$2,3-3,3$ & $2,6-3,6$ & $2,5-3,5$ & $2,4-3,4$ & $2,5-3,5$ & $2,8-3,8$ & \\
\hline
\end{tabular}




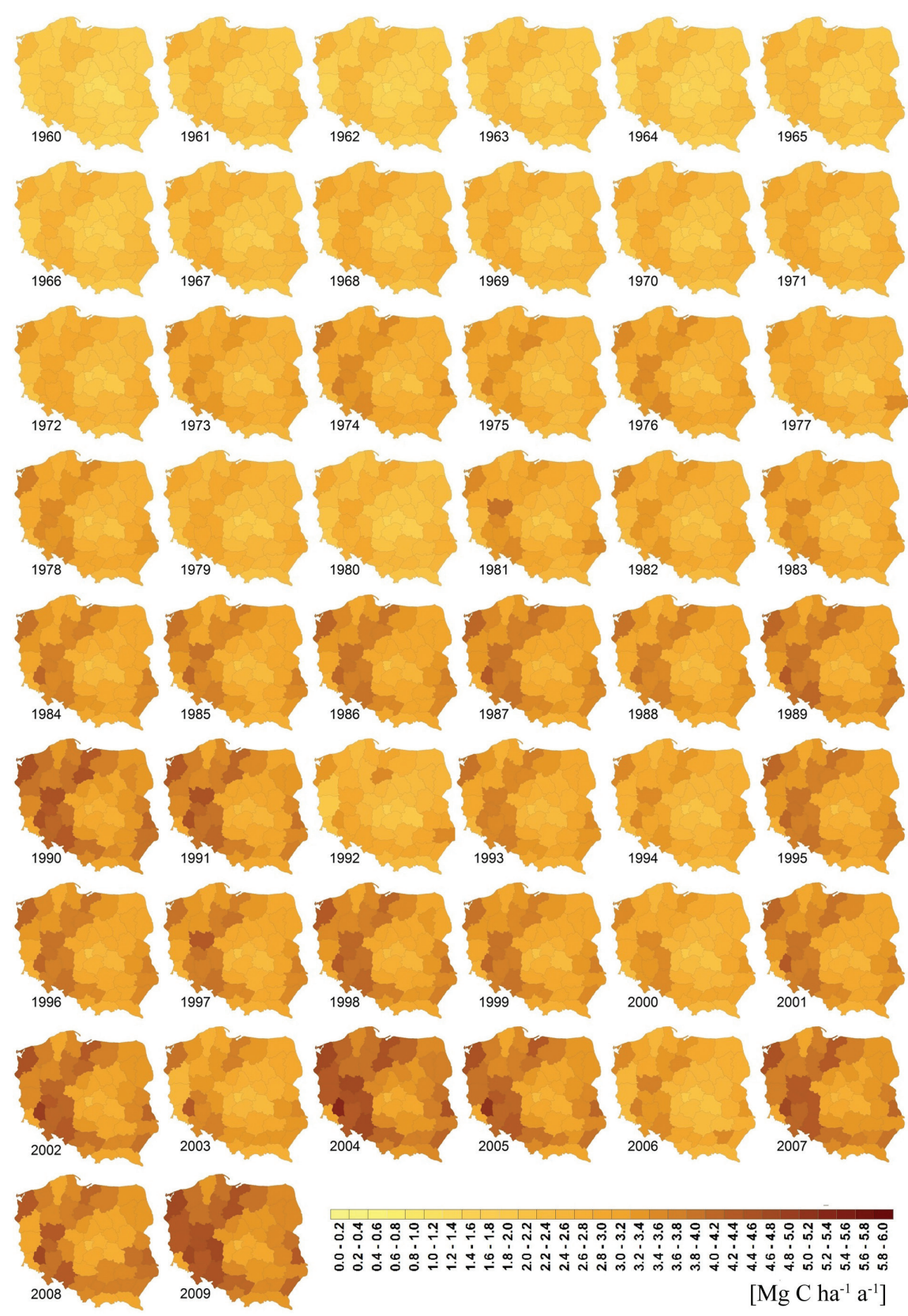

Fig. 7. Spatial and temporal distribution of $\mathrm{C}$ uptake by crops $\left[\mathrm{MgC} \mathrm{ha} \mathrm{Ca}^{-1}\right]$ for former 49 provinces in Poland during the years 1960-2009

This was mostly caused by the increased use of mineral fertilizer in both areas during this time period $\left(r^{2}=0,60\right.$ and $r^{2}=0,52$, respectively, Table 3). Mineral fertilizer application increased almost six times in both areas between 1960-1989 (Nyćkowiak et al. 2014a). Organic fertilization, in contrast to mineral fertilization, could not be related to carbon uptake $\left(r^{2}=0,01\right.$ and $r^{2}=0,22$, for areas A and B, Table 3). A sudden drop in C uptake in 1992 was observed in area $\mathrm{A}$ (reduction to $2,69 \mathrm{Mg} \mathrm{C}^{-1}$ ), whereas this pattern was smaller in area B. The difference was caused by a sudden drop in mineral fertilizer availability $\left(r^{2}=0,53\right.$ and $r^{2}=0,49$, for areas A and B, Table 3) after the political and economic changes in Poland after 1989 (Ariaratnam, Antalik 1996). In the years 1990 and 2009 we observed very high fluctuations in carbon uptake, especially in the west. Based on the estimations found, western Poland is a better carbon sink than eastern Poland. In this way, we may conclude that the western region has higher climate change mitigation potential than the eastern part.

All the described crops in Poland absorbed in 1960 nearly $21 \mathrm{Tg} \mathrm{C}$ and in 2009 more than $32 \mathrm{Tg} \mathrm{C}$. Most of the absorbed carbon will be quickly returned to the atmosphere because the yield will be used for food production or as fodder. But $3 \%$ of the total assimilated carbon remains in soil and in microorganisms (Kuzyakov, Domański 2000). According to the abovementioned quantity, from $0,66 \mathrm{Tg} \mathrm{C}$ in 1960 to $0,98 \mathrm{Tg} \mathrm{C}$ in 2009 was stored in Polish soils under crops, and thus contributed to climate change mitigation. 


\section{Acknowledgments}

The paper was financed from the EU contract No. 244122 for the years 2011-2013 Greenhouse Gas Management in European Land Use Systems, GHG - EUROPE and from the COST Action ES0804 for the years 20092013 Advancing the integrated monitoring of trace gas exchange between biosphere and atmosphere.

Bibliography

Acosta M., Juszczak R., Chojnicki B., Pavelka M., Havránková K., Leśny J., Krupková L., Urbaniak M., Machacova K., Olejnik J., 2017, $\mathrm{CO}_{2}$ fluxes from different vegetation communities on a peatland ecosystem, Wetlands, 37, 423-435, DOI: $10.1007 / \mathrm{s} 13157-017-0878-4$

Anderson T.R., Hawkins E., Jones P.D., 2016, $\mathrm{CO}_{2}$, the greenhouse effect and global warming: from the pioneering work of Arrhenius and Callendar to today's Earth System Models, Endeavour, 40 (3), 178-187, DOI: 10.1016/j.endeavour.2016.07.002

Andres R.J., Boden T.A., Bréon F.M., Ciais P., Davis S., Erickson D., Gregg J.S., Jacobson A., Marland G., Miller J., Oda T., Olivier J.G.J., Raupach M.R., Rayner P., Treanton K., 2012, A synthesis of carbon dioxide emissions from fossil-fuel combustion, Biogeosciences, 9, 1845-1871, DOI: 10.5194/ bg-9-1845-2012

Ariaratnam S.T., Antalik L.M., 1996, Environmental security and infrastructure in Poland: impacts from the demise of the former Soviet Union, Institute for National Security Studies, United States Air Force Academy, USA, unpublished manuscript

Bański J., 2007, Geography of Polish agriculture. The history of agriculture in the Polish lands, (in Polish), Polskie Wydawnictwo Ekonomiczne, Warsaw, 249 pp.

Barbour M.G., Burk J.H., Pitts W.D., 1987, Terrestrial plant ecology, Benjamin/Cummings Publishing Co., Menlo Park, California, $634 \mathrm{pp}$.

Bousquet P., Peylin P., Ciais P., Le Quéré C., Friedlingstein P., Tans P.P., 2000, Regional changes in carbon dioxide fluxes of land and oceans since 1980, Science, 290 (5495), 1342-1346, DOI: $10.1126 /$ science.290.5495.1342

Bouwman A.F., Boumans L.J.M., Batjes N.H., 2002a, Emissions of $\mathrm{N}_{2} \mathrm{O}$ and $\mathrm{NO}$ from fertilized fields: Summary of available measurement data, Global Biogeochemical Cycles, 16 (4), 6/1-6/13, DOI: 10.1029/2001GB001811

Bouwman A.F., Boumans L.J.M., Batjes N.H., 2002b, Modeling global annual $\mathrm{N}_{2} \mathrm{O}$ and $\mathrm{NO}$ emissions from fertilized fields, Global Biogeochemical Cycles, 16 (4), 28/1-28/9, DOI: 10.1029/2001GB001812

GUS, 1966, Agricultural Statistical Yearbook 1945-1965, Volume 2, (in Polish), Central Statistical Office of Poland, Warsaw
GUS, 1967a, District economic development in the years 19501965, (in Polish), Central Statistical Office of Poland, Warsaw GUS, 1967b, District Statistics 1966, (in Polish), Central Statistical Office of Poland, Warsaw

GUS, 1967c, District Statistics 1967, (in Polish), Central Statistical Office of Poland, Warsaw

GUS, 1970, Consumption of synthetic, calcium and organic fertilizers 1924/25 - 1937/38, 1945/46 - 1969/70, (in Polish), Central Statistical Office of Poland, Warsaw

GUS, 1971, Agricultural Statistical Yearbook 1971, (in Polish), Central Statistical Office of Poland, Warsaw

GUS, 1976, Provinces Yearbook 1976,(in Polish), Central Statistical Office of Poland, Warsaw

GUS, 1978, Statistical Yearbook of Agriculture and Food Economy 1978, (in Polish), Central Statistical Office of Poland, Warsaw

GUS, 1982, Statistical Yearbook of Agriculture and Food Economy 1982, (in Polish), Central Statistical Office of Poland, Warsaw GUS, 1985, Agriculture and food economy 1984, (in Polish), Central Statistical Office of Poland, Warsaw

GUS, 1986, Statistical Yearbook of Agriculture and Food Economy 1986, (in Polish), Central Statistical Office of Poland, Warsaw GUS, 1987, Statistical Yearbook of Agriculture and Food Economy 1987, (in Polish), Central Statistical Office of Poland, Warsaw GUS, 1990, Consumption of synthetic and calcium fertilizers in the economic year 1989/90, (in Polish), Central Statistical Office of Poland, Warsaw

GUS, 1992a, Agriculture and food economy 1986-1990, (in Polish), Central Statistical Office of Poland, Warsaw

GUS, 1992b, Consumption of synthetic and calcium fertilizers in the economic year 1991/92, (in Polish), Central Statistical Office of Poland, Warsaw

GUS, 1993, Consumption of synthetic and calcium fertilizers in the economic year 1992/93, (in Polish), Central Statistical Office of Poland, Warsaw

GUS, 1994a, Agriculture and food economy 1993, (in Polish), Central Statistical Office of Poland, Warsaw

GUS, 1994b, Consumption of synthetic and calcium fertilizers in the economic year 1993/94, (in Polish), Central Statistical Office of Poland, Warsaw)

GUS, 1995, Consumption of synthetic and calcium fertilizers in the economic year 1994/95, (in Polish), Central Statistical Office of Poland, Warsaw

GUS, 1996, Consumption of synthetic and calcium fertilizers in the economic year 1995/96, (in Polish), Central Statistical Office of Poland, Warsaw

GUS, 1997, Consumption of synthetic and calcium fertilizers in the economic year 1996/97, (in Polish), Central Statistical Office of Poland, Warsaw

GUS, 1998, The means of production in agriculture 1997, (in Polish), Central Statistical Office of Poland, Warsaw 
GUS, 1999a, Agricultural Statistical Yearbook 1998, (in Polish), Central Statistical Office of Poland, Warsaw

GUS, 1999b, The means of production in agriculture 1998, (in Polish), Central Statistical Office of Poland, Warsaw

GUS, 2000, The means of production in agriculture 1999, (in Polish), Central Statistical Office of Poland, Warsaw

GUS, 2001a, Agricultural Statistical Yearbook 2001, (in Polish), Central Statistical Office of Poland, Warsaw

GUS, 2001b, The means of production in agriculture 2000, (in Polish), Central Statistical Office of Poland, Warsaw

GUS, 2002, The means of production in agriculture 2001, (in Polish), Central Statistical Office of Poland, Warsaw

GUS, 2003, The means of production in agriculture 2002, (in Polish), Central Statistical Office of Poland, Warsaw

GUS, 2004, The means of production in agriculture 2003, (in Polish), Central Statistical Office of Poland, Warsaw

GUS, 2005a, Statistical Yearbook of Agriculture and Rural Areas 2005, (in Polish), Central Statistical Office of Poland, Warsaw

GUS, 2005b, The means of production in agriculture 2004, (in Polish), Central Statistical Office of Poland, Warsaw

GUS, 2006a, Statistical Yearbook of Agriculture and Rural Areas 2006, (in Polish), Central Statistical Office of Poland, Warsaw

GUS, 2006b, The means of production in agriculture 2005, (in Polish), Central Statistical Office of Poland, Warsaw

GUS, 2007a, Statistical Yearbook of Agriculture and Rural Areas 2007, (in Polish), Central Statistical Office of Poland, Warsaw

GUS, 2007b, The means of production in agriculture 2006, (in Polish), Central Statistical Office of Poland, Warsaw

GUS, 2008a, Statistical Yearbook of Agriculture and Rural Areas 2008, (in Polish), Central Statistical Office of Poland, Warsaw

GUS, 2008b, The means of production in agriculture 2007, (in Polish), Central Statistical Office of Poland, Warsaw

GUS, 2009a, Agricultural Statistical Yearbook 2009, (in Polish), Central Statistical Office of Poland, Warsaw

GUS, 2009b, The means of production in agriculture, marketing year 2008/2009, (in Polish), Central Statistical Office of Poland, Warsaw

GUS, 2010, Agricultural Statistical Yearbook 2010, (in Polish), Central Statistical Office of Poland, Warsaw

GUS, 2014, online: www.stat.gov.pl

Houghton R.A., Hall F., Goetz S.J., 2009, Importance of biomass in the global carbon cycle, Journal of Geophysical Research, 114 (G2), DOI: 10.1029/2009JG000935

Houghton R.A., Schlesinger W.H., Brown S., Richards J.F., 1985, Carbon dioxide exchange between the atmosphere and terrestrial ecosystems, [in:] Atmospheric carbon dioxide and the global carbon cycle, J.R. Trabalka (ed.), University Press of the Pacific, 113-140

IPCC, 2006a, Good practice guidance and uncertainty management in national greenhouse inventories, Intergovernmental
Panel on Climate Change, available at https://www.ipccnggip.iges.or.jp/public/gp/english/ (data access 20.11.2017)

IPCC, 2006b, Guidelines for national greenhouse gas inventories, S. Eggleston, L. Buendia, K. Miwa, T. Ngara, K. Tanabe (eds.), Intergovernmental Panel on Climate Change, available at https://www.ipcc-nggip.iges.or.jp/ public/2006gl/ (data access 20.11.2017)

Khedr A., Serag M., Shaaban H., Abogadallah G., 2017, Differential responses of aquatic and aerobic forms of Echinochloa crus-galli (L.) Beauv. and E. colona (L.) Link. by morphophysiological and molecular analysis, Environment, Earth and Ecology, 1 (1), 81-93, DOI: 10.24051/eee/69225

Kirschbaum M.U.F., Eamus D., Gifford R.M., Roxburgh S.H., Sands P.J., 2001, Definitions of some ecological terms commonly used in carbon accounting, [in:[ Net ecosystem exchange. Wokshop Proceedings. CRC for Greenhouse Accountig, M.U.F. Kirschbaum, R. Mueller (eds.), The Communications Office, Cooperative Research Centre for Greenhouse Accounting, Canberra, 2-5

Kuzyakov Y., Domański G., 2000, Carbon input by plants into the soil, Journal of Plant Nutrition and Soil Science, 163 (4), 421-431,DOI: 10.1002/1522-2624(200008)163:4<421::AIDJPLN421>3.0.CO;2-R

Magalhães T.M., 2015, Allometric equations for estimating belowground biomass of Androstachys johnsonii Prain, Carbon Balance and Management, 10 (16), 1-15, DOI: 10.1186/ s13021-015-0027-4

Nyćkowiak J., Leśny J., Merbold L., Niu S., Haas E., Kiese R., Butterbach-Bahl K., Olejnik J., 2014a, Direct $\mathrm{N}_{2} \mathrm{O}$ emission from agricultural soils in Poland between 1960 and 2009, Regional Environmental Change, 14 (3), 1073-1082, DOI: 10.1007/s10113-013-0543-2

Nyćkowiak J., Leśny J., Olejnik J., 2014b, Changes in meteorological conditions in a Polish city, 1848-2009, Polish Journal of Environmental Studies, 23 (1), 149-155

Ontl T.A., Schulte L.A., 2012, Soil carbon storage, Nature Education Knowledge, 3 (10), 35, available at https:// www.nature.com/scitable/knowledge/library/soil-carbonstorage-84223790 (data access 20.11.2017)

Owensby C.E., Ham J.M., Knapp A.K., Auen L.M., 1999, Biomass production and species composition change in a tallgrass prairie ecosystem after long-term exposure to elevated atmospheric $\mathrm{CO}_{2}$, Global Change Biology, 5 (5), 497-506, DOI: 10.1046/j.1365-2486.1999.00245.x

Schlesinger W.H., Andrews J.A., 2000, Soil respiration and the global carbon cycle, Biogeochemistry, 48 (1), 7-20, DOI: 10.1023/A:1006247623877

Seinfeld J.H., Pandis S.N., 2016, Atmospheric chemistry and physics: from air pollution to climate change, Wiley, $1152 \mathrm{pp}$. Shafea A.A., Dawood M.F., Zidan M.A., 2017, Wheat seedlings 
traits as affected by soaking at titanium dioxide nanoparticles, Environment, Earth and Ecology 1 (1), 102-111, DOI: $10.24051 /$ eee/68607

Stehfest E., Bouwman L., 2006, $\mathrm{N}_{2} \mathrm{O}$ and NO emission from agricultural fields and soils under natural vegetation: summarizing available measurement data and modeling of global annual emissions, Nutrient Cycling Agroecosystems, 74 (3), 207-228, DOI: 10.1007/s10705-006-9000-7
Venhari A.A., Tenpierik M., Hakak A.M., 2017, Heat mitigation by greening the cities, a review study, Environment, Earth and Ecology, 1 (1), 5-32, DOI: 10.24051/eee/67281

Walter H., Lieth H., 1967, Klimadiagram-Weltatlas, VEB Gustav Fischer Verlag, Jena 